\title{
Fortolkende beskrivelse er en egnet metode for sykepleiere og forskere
}

\section{Forskningsmetoden tar utgangspunkt i helsepersonells nærhet til praksis og orientering mot pasienten. Formålet er å utvikle klinisk anvendbar kunnskap.}

\section{Janice Andersen}

Genetisk veileder

Nasjonalt kompetansesenter for porfyrisykdommer, Avdeling for medisinsk biokjemi og farmakologi, Haukeland universitetssjukehus

Tina Taule

Ergoterapispesialist og forskings- og fagutviklingsleder

Ergoterapiavdelingen, Ortopedisk klinikk, Haukeland universitetssjukehus

Forskning

Kvalitativ studie

Metode

Akademikerne

Interpretive description

Fortolkende beskrivelse

\section{Hovedbudskap}

Vi introduserer metoden fortolkende beskrivelse, som vi mener sykepleiere og andre helsefaglige forskere kan benytte hvis de ønsker en praksisrettet kvalitativ forskningstilnærming. Ved å bruke fortolkende beskrivelse kan forskerne utvikle anvendbar kunnskap som er tilpasset vår komplekse og kliniske hverdag. Metoden tar utgangspunkt i helsefaglig praksis. Den imøtekommer et behov som ikke dekkes av mer teoretiserende og akademiske kvalitative metoder fra fagtradisjonene filosofi, sosiologi og antropologi. 
I denne artikkelen introduserer vi fortolkende beskrivelse, oversatt fra engelsk interpretive description (1), som en hensiktsmessig kvalitativ metode for medisinsk og helsefaglig forskning.

Metoden er utviklet av den kanadiske professoren i sykepleievitenskap, Sally Thorne og hennes medarbeidere (25), og tar først og fremst utgangspunkt i og anerkjenner at helsefagene er anvendte disipliner, og ikke teoretiserende av natur.

\section{Forskningsprosessen og -spørsmål}

Fortolkende beskrivelse henter inspirasjon fra ulike tradisjoner og tillater å bruke de analysemetodene forskeren vurderer som hensiktsmessige for å kunne besvare forskningsspørsmålet. Metoden blir derfor betegnet som pragmatisk og ikke-kategorisk.

I fortolkende beskrivelse utvikles metoden i et dynamisk samspill mellom forskeren og forskningsprosessen, der metoden tilpasses forskningen, og ikke omvendt. Samtidig respekteres grunntrekkene i ulike tradisjoner, og metoden er sterkt inspirert av fenomenologi og grounded theory.

Hvis forskeren skal benytte fortolkende beskrivelse, bør problemstillingen være praksisbasert og egnet til å ekspandere og utfordre eksisterende kunnskap.

Eksempler på forskningsspørsmål kan være følgende: «Hvilke erfaringer har slagpasienter med rehabilitering i eget hjem?» (6) eller «Hvilke psykososiale konsekvenser har prediktiv gentesting for akutt intermitterende porfyri (AIP) hos mindreårige?» (7)

\section{Valg av deltakere}

For at et forskningsspørsmål skal kunne bli besvart ved å bruke fortolkende beskrivelse, bør datamaterialet være rikt og variert, men det er også viktig å begrense antallet deltakere for å kunne håndtere bearbeidingen av dataene.

Det finnes ingen objektive kriterier for størrelsen på utvalget, og det anbefales at forskeren holder muligheten åpen for å utvide utvalget hvis det blir nødvendig. 
I fortolkende beskrivelse anses ikke begrepet «metning» som et mål, eller som noe det er mulig å oppnå. Funnene skal ikke dekke hele spekteret av potensielt tilgjengelige fenomener, men presentere vesentlige erfaringer om temaet forskeren vil belyse.

Utvalget kan være strategisk, det vil si at forskeren velger deltakere med spesielle kjennetegn eller erfaringer som kan ha betydning for det forskeren $\varnothing$ nsker å unders $\varnothing$ ke. I studien som unders $\varnothing$ kte erfaringer med rehabilitering i hjemmet, intervjuet forskerne personer som selv hadde fått slik rehabilitering.

Forskerne kunne også ha valgt å intervjue pårørende eller behandlere, og sannsynligvis fått annerledes, men nyttig informasjon. Alternativt kunne de også brukt et teoretisk generert utvalg.

Begrepet stammer fra grounded theory og innebærer at forskeren etter å ha oppdaget «mønstre» eller kategorier forfølger disse kategoriene ved å lete etter spesielle caser som kan belyse kategoriene ytterligere.

Hvis det for eksempel i prosjektet med hjemmerehabilitering kom frem at en gruppe deltakere ikke hadde gode erfaringer, kunne forskerne aktivt prøvd å finne aktuelle kilder som kunne belyse det.

\section{Valg av metode for datainnsamling}

Aktuelle datasamlingsmetoder hvis man bruker fortolkende beskrivelse, er for eksempel intervju, deltakende observasjon eller dokumentanalyse, og datainnsamlingsmetodene kan gjerne trianguleres (5).

Stadig flere helsefaglige forskningsprosjekter benytter også mixed methods blant annet for å fremme samarbeid på tvers av fagfelter. Fortolkende beskrivelse anerkjenner bruk av både subjektiv og objektiv kunnskap og kan derfor være en spesielt egnet metode for prosjekter som benytter mixed methods (5. s. 49).

\section{Ordliste}

Bias: I forskning: når resultater eller slutninger systematisk avviker fra det egentlig rette. Bias kan oppstå på grunn av feil eller unøyaktigheter ved utvalg, unders $\varnothing$ kelsesobjekter, valg av unders $\varnothing$ kelsesmetode eller vurdering av resultater. 
Eklektisk: Her: å blande elementer fra ulike teoretiske retninger for å skape nye løsninger.

Epistemologi: Erkjennelsesteori - læren om kunnskap og innsikt.

Etnografi: En helhetlig beskrivelse av sosiale og kulturelle prosesser gjennom nærstudier av sosialt liv, gjerne kalt deltakende observasjon.

Fenomenologi: Et begrep som vanligvis referer til en filosofisk tradisjon med utspring i Edmund Husserls filosofi og metode. I enkelte kontekster brukes det også i en videre forstand til å referere til de kvalitative eller fenomenale aspektene ved vår erfaring generelt.

Grounded theory: Forskningsmetode innen sosiologi og psykologi, der man starter med «blanke ark» i et fors $\varnothing k$ på å utvikle en teori ut fra et datasett.

Kilde: Store norske leksikon

\section{Analyseprosessen i fortolkende beskrivelse}

Fortolkende beskrivelse tilbyr ikke et sett med ferdige analysetrinn som forskeren kan følge i analyseprosessen, men henviser til anerkjente metoder som den uerfarne (eller erfarne) forskeren kan støtte seg til. Selv har vi god erfaring med å bruke systematisk tekstkondensering (8) i analyseprosessen $(6,9,10)$.

\section{Kvalitativ analyse er en kreativ prosess}

Ingen analysemetoder $b \varnothing r$ imidlertid benyttes ukritisk av forskeren fordi det da er fare for at oppmerksomhet på teknikk overskygger den kreative prosessen, slik at forskeren sitter igjen med tomme og meningsløse kategorier (5, s. 170).

Skal vi lykkes med å skape relevante og anvendbare forskningsresultater, trenger vi noe mer enn kvalitativ beskrivelse, ifølge Thorne (3). Fortolkende beskrivelse har derfor eksplisitt oppmerksomhet på det fortolkende aspektet, og målet er konseptualisering (begrepsdannelse) av fenomener og forståelse av meningsinnhold (5).

\section{$\equiv$ «Ingen analysemetoder bør benyttes ukritisk av forskeren.»}


Selv om fortolkende beskrivelse ikke er en metodisk oppskrift, er det noen elementer i analyseprosessen som Thorne vektlegger og anbefaler: Datasamling og analyse gjøres fortløpende, slik at de gjensidig kan påvirke hverandre, såkalt konstant komparativ metode $(1,11)$.

Helhetsperspektiv og dybdeforståelse er viktig, og forskeren bør derfor unngå for detaljert eller tidlig koding. Kreativitet er vesentlig, men forskeren må gjøre rede for og anerkjenne sin tolkende autoritet.

Med det mener Thorne at kvalitativ forskning alltid inneholder et element av tolkning, samtidig som leseren trenger å vite at forskerens tolkninger er troverdige. Det er derfor viktig å gi tilstrekkelig informasjon om grunnlaget og bakgrunnen for de tolkningene som gjøres.

\section{Forforståelsen må tydeliggjøres og utfordres}

I tillegg må forskerens bakgrunn, forforståelse og perspektiv presenteres. Det å tilsidesette egen forforståelse, såkalt bracketing, som er et viktig element i fenomenologi, er derfor ikke et ideal i fortolkende beskrivelse (5).

\section{三 «Selv om noe opptrer hyppig, er ikke det ensbetydende med relevans eller viktighet.»}

Thorne (5) advarer mot en prematur avslutning av analysen fordi det kan forhindre en full utforsking av dataene. Hvis funnene passer for godt til forskerens antakelser, skyldes det sannsynligvis en bekreftelse av forskerens forforståelse og ikke ny kunnskap, såkalt over-inscription of self (5, s. 196), noe som er problematisk i all kvalitativ forskning.

\section{Tolkning av observasjoner som forekommer ofte}

Et annet punkt Thorne advarer mot, er å feiltolke frekvens. Selv om noe opptrer hyppig, er ikke det ensbetydende med relevans eller viktighet. For eksempel kan det hende at alle deltakerne i en fokusgruppe går med jeans, men vi vil aldri anta at å gå med jeans har noen betydning for funnene i studien.

På samme måte skal forskeren være forsiktig med å anta at en observasjon eller hendelse opptrer oftere enn den gjør. 


\section{Hvilke funn skal vektlegges?}

Studiens hensikt og målgruppe har betydning for hvordan resultatene presenteres. Hvilke funn som vektlegges, kan derfor være styrt av hvem som er mottakerne av forskningen.

I en fokusgruppestudie som utforsket erfaringene til personer med en sjelden sykdom, porphyria cutanea tarda (PCT) (9), kom det frem at kløe var et stort problem for flere av deltakerne. Kløen var ikke et symptom som ble nevnt i tidligere litteratur, og forskerne kunne heller ikke trekke noen konklusjon om at kløen skyldtes PCT.

Like fullt ble problemet med kløe et viktig funn som ble oppfattet som interessant for fagmiljøet. Funnet bidro senere til at et spørreskjema ble endret for å fange opp mer informasjon om kløe hos pasientgruppen.

I annen kvalitativ forskning ville kanskje ikke dette temaet blitt betraktet som et spesielt spennende funn, og i et fenomenologisk prosjekt ville kanskje kløe som fenomen vært interessant å utforske. Her ble imidlertid fagmiljøet som målgruppe viktig for at nettopp kløe ble et av hovedfunnene.

\section{Forskningens troverdighet}

Hva som bidrar til en troverdig håndtering av feil og mangler som forskeren selv eller metoden påfører forskningsresultatene, vil alltid være en viktig diskusjon. Generelle og overordnede kvalitetskrav, akseptert på tvers av ulike kvalitative tilnærminger, gjelder også for fortolkende beskrivelse og er nøye beskrevet av Thorne (5).

Et av spenningsfeltene i den kvalitative debatten er avveiningen mellom å rendyrke og forholde seg strengt til én metodisk tilnærming (epistemologisk purisme), eller om forskeren kan mikse og låne der det er nødvendig (epistemologisk plurisme) (13).

\section{Bruk av såkalte gullstandarder garanterer ikke kvalitet}

Fortolkende beskrivelse oppfordrer til det sistnevnte og har en såkalt eklektisk tilnærming og plasserer seg slik langt ute på den pluralistiske siden. Pragmatisme og metodens anvendbarhet for det aktuelle forskningsspørsmålet er derfor viktigere for forskningens kvalitet enn å imøtekomme krav satt av såkalte gullstandarder (5). 
Hvilke svakheter som bør trekkes frem i den enkelte studien, avhenger av det aktuelle forskningsspørsmålet, studiens formål og valgt metode. Når troverdighet i en fortolkende, beskrivende studie evalueres, må derfor leserens oppmerksomhet være på situasjonen heller enn på filosofisk tradisjon.

Fortolkende beskrivelse håndterer individuelle og faglige skjevheter (bias) ved å bruke dialog og transparente refleksjoner, slik at leseren selv kan følge forskerens beslutningsprosesser og vurdere om aktuelle avgjørelser har sitt utspring fra data eller ikke.

\section{Forskningen må være relevant for praksisfeltet}

At helsefagene ikke er akademiske disipliner i utgangspunktet, gir også spesielle utfordringer når det gjelder validitet. Fordi forskning basert på fortolkende beskrivelse søker å endre praksis, innebærer det spesifikke kredibilitetskriterier som Thorne kaller «moralsk forsvarlighet», «disiplinær relevans» og «pragmatisk obligasjon».

Med de nevnte kredibilitetskriteriene mener Thorne at vi må kunne forsvare at den kunnskapen vi henter, er nødvendig og nyttig for dem som studeres, at den er relevant for fagfeltet, og ikke minst at forskeren alltid må ha i bakhodet at kunnskapen som kommer frem, kan bli brukt i praksis (5, s. 236-7, 14).

Det må altså gjøres en grundig avveining av hvorfor forskningen er viktig, og hvordan forskningsresultatet kan komme både pasienten og fagfeltet til gode. På bakgrunn av slike spesielle utfordringer har helsefaglig kvalitativ forskning blitt foreslått som en egen under-disiplin innen kvalitativ forskning generelt (15).

Fortolkende beskrivelse er ikke en «snarvei» til kvalitativ metode gjennom anarkistisk bruk av ulike genrer. Den er heller utfordrende, fordi den krever at alle steg og valg i forskningsprosessen er gjort rede for, basert på intern logikk og sammenheng mellom problemstilling, utvalg, datasamling, analyse og presentasjon av resultatet (12). 


\section{Teoriens plass i fortolkende beskrivelse}

Fortolkende beskrivelse tar utgangspunkt i helsepersonells nærhet til praksis og orientering mot pasienten. Møtet mellom pasienten og helsearbeideren vil alltid være praktisk og konkret, og innholdet formes av tid, sted og dem som befinner seg i situasjonen.

\section{Helsefagene er i utgangspunktet ikke akademiske disipliner}

Denne anerkjennelsen av at helsefagene er anvendte disipliner og ikke akademiske og teoretiserende av natur, er kanskje et av de viktigste skillene mellom fortolkende beskrivelse og de mer kjente kvalitative tilnærmingene som etnografi, grounded theory og fenomenologi.

Disse vitenskapsteoretiske retningene ble utviklet i akademiske tradisjoner som sosiologi, filosofi og sosialantropologi, tradisjoner der det har vært nødvendig å signalisere klart hvilken teoretisk diskusjon forskeren henvendte seg til.

Denne akademiske tradisjonen har medført en konvensjon om at all anerkjent kvalitativ forskning trenger en eksplisitt teoretisk forankring.

\section{Et kunstig krav om teoretisk posisjonering}

Resultatet er at en del forskere innen helsefaglig forskning har anvendt lite hensiktsmessige og «hule» fors $\varnothing \mathrm{k}$ på å imøtegå «kravet» om teoretisk posisjonering, eller at kravet til teoriforståelse har overskygget utviklingen av kunnskap som er anvendelig for helsefagene, som jo er vårt hovedanliggende.

Thorne mener derimot at en profesjon som for eksempel sykepleie og kunnskapen de bygger sin kliniske forståelse på, altså disiplinær tenkning, kan være et tilstrekkelig teoretisk grunnlag også for forskning.

Derfor trenger man ikke å tolke data gjennom andre mer eksplisitte teorier i anvendte fag som for eksempel sykepleie (16). På bakgrunn av dette har Thorne omtalt fortolkende beskrivelse som «grunnleggende ateoretisk». 


\section{Teoridanning er ikke et mål i fortolkende beskrivelse}

Imidlertid er det omdiskutert at for eksempel sykepleie i seg selv kan forstås som teori (17). Det som er klart, er at teoretisering i seg selv aldri vil være et mål når man bruker fortolkende beskrivelse.

\section{三 «Teoretisering i seg selv vil aldri være et mål når man bruker fortolkende beskrivelse.»}

Satt på spissen kan vi si at der teoretisering er tenkt som et mål i seg selv i samfunnsvitenskapene, er teori for klinikeren et middel for å kunne forstå enkeltindividet, klienten eller pasienten (5, s. 27).

Tanken om at en metode kan være «ateoretisk», er imidlertid problematisk, fordi all (kvalitativ) forskning er basert på fundamentale ideer og strukturer, såkalt forforståelse (16).

Thorne foreslår derfor at kunnskapsgrunnlaget i en profesjon anses som teori fordi det påvirker hva vi ønsker å observere, hva vi ser når vi observerer, og hvordan vi oppfatter og forstår observasjonene (5, s. 74).

Kunnskapen som forskeren bringer inn i prosjektet, og problemets natur stammer fra ideer og strukturer som også har teoretiske elementer i seg. Forskning, som har til hensikt å influere praksis, er ikke tjent med å la seg dominere eller styre av underliggende teoretiske rammeverk, fordi forskeren risikerer bare å bekrefte det som allerede er kjent.

Fortolkende beskrivelse forutsetter derfor at forskeren synliggjør, utfordrer og raffinerer sin forforståelse og vurderer alternative tolkninger aktivt. Underveis i analyseprosessen kan imidlertid bruk av teori, i den hensikt å utvikle en dypere forståelse av det empiriske materialet, være hensiktsmessig (5).

Teori anvendt som en «boksåpner» (18) kan gi verdifull tilgang til forskningsfeltet og forskningsresultatene samt heve resultatene ut over det naivt empiristiske.

Teori forstås altså på flere måter, som disiplinær tenkning, som forforståelse, og som den mer klassiske bruken av begrepet, der en teori er eksplisitt og navngitt. A kalle fortolkende beskrivelse «grunnleggende ateoretisk» er imidlertid etter vår mening upresist. 


\section{Hva er ulikt annen kvalitativ forskning?}

Fortolkende beskrivelse er ikke en metode som hevder å være revolusjonerende ny, men den bringer likevel noe nytt og essensielt til det kvalitative forskningsfeltet.

Renate hevder i sin artikkel at ved ikke å følge en bestemt filosofisk eller akademisk tradisjon sorterer fortolkende beskrivelse under forskningsgenren generiske kvalitative metoder (19).

Selve analyseprosessen behøver ikke være nevneverdig forskjellig fra andre metoder, og de grunnleggende kvalitetskriteriene vil være de samme. Så hva er det da som skiller fortolkende beskrivelse fra andre kvalitative tilnærminger?

\section{Det er lov å bryte genre}

Ved fortolkende beskrivelse er det blant annet en klar presisering av at forskeren ikke nødvendigvis kommer frem til gode forskningsresultater gjennom å følge rigide metodologiske regler utviklet i andre forskningstradisjoner enn den helsefaglige.

Snarere tvert imot, ved å anerkjenne de kreative prosessene i kvalitativ forskning og benytte en pragmatisk tilnærming gjennom å låne der det er hensiktsmessig, trenger ikke forskeren være redd for å bryte genrer.

Forskjellene mellom fortolkende beskrivelse og de større kvalitative forskningstradisjonene tydeliggjøres best når vi sammenlikner målsetting og intensjon.

\section{Formålet er anvendbar kunnskap}

Der formålet med fortolkende beskrivelse er å utvikle klinisk anvendbar kunnskap, søker etnografi å forstå menneskets universelle natur ved å sette søkelyset på variasjoner slik de fremstår innen en gitt kultur.

Det har vært hevdet at fortolkende beskrivelse ikke bringer noe nytt til forskningsfeltet, men heller er en del av en «grounded theory-bevegelse» (20).

Ambisjonen med grounded theory er imidlertid å utvikle nye teorier på bakgrunn av sosiale prosesser og menneskelig handling. Søkelyset i fortolkende beskrivelse rettes, som i grounded theory, mot menneskelig handling utført i samsvar med og på bakgrunn av en tolkning av omgivelsene. 
Men der grounded theory har en teoridannende målsetting, er fortolkende beskrivelse tydelig på at teoretisering ikke er en målsetting.

\section{三 «Forskeren kan ved å bruke fortolkende beskrivelse også utnytte ekspertkunnskap og egne holdninger i kunnskapsutviklingen.»}

Ved bruk av fenomenologi søkes essensen i levd erfaring, gjennom å sette til side sin egen forforståelse (bracketing), mens forskeren ved å bruke fortolkende beskrivelse også kan utnytte ekspertkunnskap og egne holdninger i kunnskapsutviklingen (1).

Forskeren velger da design og utvalg på bakgrunn av tidligere kunnskap og anerkjenner både teoretisk og klinisk kjennskap til feltet, samtidig som han eller hun ikke skal la denne kunnskapen «overvelde dataene» (3).

Fortolkende beskrivelse skiller seg også fra kvalitativ beskrivelse ved at den antar at helsearbeidere ikke nøyer seg med rene beskrivelser, men alltid vil søke mening og forklaring (3).

Vi gir her en svært forenklet beskrivelse av store metodologiske retninger, men peker også på at det ikke bør være nødvendig for den helsefaglige forskeren å sette seg inn i de store og dype metodologiske diskusjonene innen de tradisjonelle feltene for å kunne bidra med kvalitativ forskning av høy kvalitet.

Terskelen for å begi seg ut på et fenomenologisk prosjekt eller grounded theory-prosjekt kan være høy for forskere som ikke har sin grunnutdanning innen akademiske disipliner.

Ifølge Sandelowski bør helsefaglige forskere vie mindre oppmerksomhet på forskningens filosofiske forutsetninger, og heller фke oppmerksomheten på empiri, resultat og kliniske implikasjoner. Slik kan den helsefaglige forskeren bidra med sin unike kompetanse og utføre forskning som er relevant, praksisnær og anvendbar (2). 


\section{Konklusjon}

Gjennom å presentere og diskutere grunnleggende kjennetegn ved fortolkende beskrivelse håper vi forskere som $\varnothing$ nsker en praksisrettet vinkling på sine kvalitative prosjekter eller mixed methods-prosjekter har fått et innblikk i det vi mener er en hensiktsmessig og relevant forskningstilnærming.

Fortolkende beskrivelse har sitt epistemologiske ståsted i helsefaglig praksis, men anerkjenner samtidige teoriens plass for å utvikle dybdeforståelse av fenomener.

Derfor møter fortolkende beskrivelse et behov som ikke dekkes av mer teoretiserende og akademiske kvalitative metoder, med utspring i fagtradisjoner som filosofi, sosiologi eller antropologi.

\section{Referanser}

1. Lomborg K, Ankersen L. Fortolkende beskrivelse. Klinisk Sygepleje. 2010;24(1):7-15.

2. Thorne S. Interpretive description. California: Left Coast Press; 2008.

3. Thorne S, Kirkham S, O'Flynn-Magee K. The analytic challenge in interpretive description. IJQM. 2004;3(1):1-11.

4. Thorne S, Kirkham SR, MacDonald-Emes J. Interpretive description: a noncategorical qualitative alternative for developing nursing knowledge. Res Nurs Health. 1997;20(2):169-77.

5. Thorne S. Interpretive description. 2. utg. California: Left Coast Press; 2016.

6. Taule T, Strand LI, Skouen JS, Råheim M. Striving for a life worth living: stroke survivors' experiences of home rehabilitation. Scand J Caring Sci. 2015;29(4):651-61.

7. Andersen J, Sandberg S, Raaheim M, Gjengedal E. Psychosocial aspects of predictive genetic testing for acute intermittent porphyria in Norwegian minors. JIMD Rep. 2011;1:1-7.

8. Malterud K. Systematic text condensation: a strategy for qualitative analysis. Scand J Public Health. 2012;40(8):795805 . 
9. Andersen J, Gjengedal E, Sandberg S, Raheim M. A skin disease, a blood disease or something in between? An exploratory focus group study of patients' experiences with porphyria cutanea tarda. Br J Dermatol. 2015;172(1):223-9.

10. Taule T, Råheim M. Life changed existentially: a qualitative study of experiences at 6-8 months after mild stroke. Disabil Rehabil. 2014;36(25):2107-19.

11. Thorne S. Data analysis in qualitative research. Evidence Based Nursing. 2000;3(3):68-70.

12. Hunt MR. Strengths and challenges in the use of interpretive description: reflections arising from a study of the moral experience of health professionals in humanitarian work. Qual Health Res. 2009;19(9):1284-92.

13. Whittemore R, Chase SK, Mandle CL. Validity in qualitative research. Qual Health Res. 2001;11(4):522-37.

14. Hunt MR. Book review: Sally Thorne interpretive description. Qual Health Res. 2011;21(2):292-4.

15. Morse JM. How different is qualitative health research from qualitative research? Do we have a subdiscipline? Qual Health Res. 2010;20(11):1459-64.

16. Thorne S. The science and art of theoretical location. Evid Based Nurs. 2014;17(2):31.

17. Malterud K. Theory and interpretation in qualitative studies from general practice: Why and how? Scand J Public Health. 2016;44(2):120-9.

18. Høyer K. Hvad er teori, og hvordan forholder teori sig til metode? I: Vallgårda S, Koch L, red. Forskningsmetoder i folkesundhedsvidenskab. København: Munksgaard; 2012. s. 17-41.

19. Renate MK. Generic qualitative approaches: pitfalls and benefits of methodological mixology. International Journal of Qualitative Methods. 2014;13(1):37-52.

20. Berterö C. Developing qualitative methods - or «same old wine in a new bottle». Int J Qual Stud Health Well-being. 2015;10(1):27679. 
